14.01

\title{
Бинарные наносистемы на основе амфифильных молекулярных щеток, загруженных фотосенсибилизатором Радахлорином или наночастицами селена
}

\author{
(C) С.В. Валуева, ${ }^{1}$ Т.Е. Суханова, ${ }^{2, \uparrow}$ М.Э. Вылегжанина, ${ }^{1}$ T.К. Мелешко ${ }^{1}$ \\ ${ }^{1}$ Институт высокомолекулярных соединений РАН, \\ 199004 Санкт-Петербург, Россия \\ ${ }^{2}$ Научно-исследовательский институт синтетического каучука им. акад. С.В. Лебедева, \\ 198035 Санкт-Петербург, Россия \\ I e-mail: tat_sukhanova@bk.ru
}

Поступило в Редакцию 15 января 2020 г.

В окончательной редакции 15 января 2020 г.

Принято к публикации 17 февраля 2020 г.

\begin{abstract}
Методами атомно-силовой микроскопии, УФ-спектроскопии и динамического/статического светорассеяния изучены морфология, оптические и молекулярно-конформационные характеристики амфифильных молекулярных щеток с полиимидной основной цепью и боковыми цепями полиметакриловой кислоты, загруженных фотосенсибилизатором второго поколения Радахлорином ${ }^{\circledR}$ или наночастицами биогенного элемента - селена в нуль-валентной форме $\left(\mathrm{Se}^{0}\right)$. Показано влияние плотности прививки боковых цепей $Z$ полиметакриловой кислоты, а также введения в амфифильные молекулярные щетки Радахлорина ${ }^{\circledR}$ или $\mathrm{Se}^{0}$ на размерные, спектральные и молекулярно-конформационные характеристики синтезированных бинарных наносистем. Обнаружена немонотонная зависимость размеров наноструктур и шероховатости поверхности пленок при увеличении $Z$ в бинарных системах с Радахлорином ${ }^{\circledR}$ и, напротив, монотонное уменьшение размеров наноструктур и шероховатости поверхности для систем, содержащих наночастицы $\mathrm{Se}^{0}$.
\end{abstract}

Ключевые слова: амфифильные молекулярные щетки, фотосенсибилизатор Радахлорин ${ }^{\circledR}$, наночастицы селена в нуль-валентной форме, наноструктуры, морфология, спектральные и молекулярно-конформационные характеристики.

DOI: 10.21883/JTF.2020.09.49676.11-20

\section{Введение}

Амфифильные молекулярные щетки (АМЩ) эффективно используют в нанобиотехнологических разработках для создания на их основе наноконтейнеров в целях солюбилизации гидрофобных лекарственных препаратов или агентов и их адресной доставки $[1,2]$. Способность „загружать“ амфифильные молекулярные щетки фотосенсибилизаторами $(\Phi С)$, обладающими возможностью селективного накопления в опухолевой ткани, позволяет получать материалы со светочувствительными свойствами, необходимыми для эффективного лечения онкологических заболеваний методом фотодинамической терапии (ФДТ) [3,4]. Метод ФДТ основан на применении природных или синтетических фотосенсибилизаторов, обладающих способностью к избирательному накоплению в опухолевой ткани. При облучении светом определенной длины волны ФС переходит в активированное состояние, которое инициирует образование цитотоксических агентов - синглетного кислорода и свободных радикалов, вызывающих разрушение структурных элементов опухолевой ткани [5]. Одними из наиболее эффективных ФС являются хлорины (дигидропорфирины), которые характеризуются значительным увеличением оптической плотности в длинноволновой области спектра $(\lambda>600 \mathrm{~nm})$ и ее смещением в диапазоне длин волн $662 \mathrm{~nm}$ по сравнению с распространенными порфиринами $(632 \mathrm{~nm})$. Среди хлоринов как наиболее перспективные следует отметить водорастворимые моно-L-аспаргилхлорин е6 и другие различные формы хлорина е6, в частности, отечественные препараты нового поколения Фотодитазин ${ }^{\circledR}(Ф Д)$, Радахлорин ${ }^{\circledR}$ и Фоторан Е6 ${ }^{\circledR}$ (Хлорин Е6) [5-9]. Радахлорин ${ }^{\circledR}$ является фотосенсибилизатором второго поколения, предназначенного для флуоресцентной диагностики и ФДТ злокачественных опухолей [9]. Метод ФДТ с использованием Радахлорина ${ }^{\circledR}$ основан на его способности избирательно накапливаться в опухоли при внутривенном введении и генерировать синглетный кислород, оказывающий токсический эффект на опухолевые клетки и модифицирующее действие на их плазматические мембраны, при воздействии света с длиной волны $\lambda=662 \mathrm{~nm}$. В развитии эффекта после проведения ФДТ с препаратом Радахлорин ${ }^{\circledR}$ можно выделить 3 этапа [10]:

- 1 этап - характерная реакция на световое воздействие при ФДТ, проявляющаяся в виде отека и гиперемии зоны облучения различной выраженности;

- 2 этап - некроз опухоли, который формируется через $2-4$ дня после сеанса ФДТ;

- 3 этап - отторжение некротических масс и регенерация нормальных тканей в течение $2-8$ недель в зависимости от размеров опухоли. 


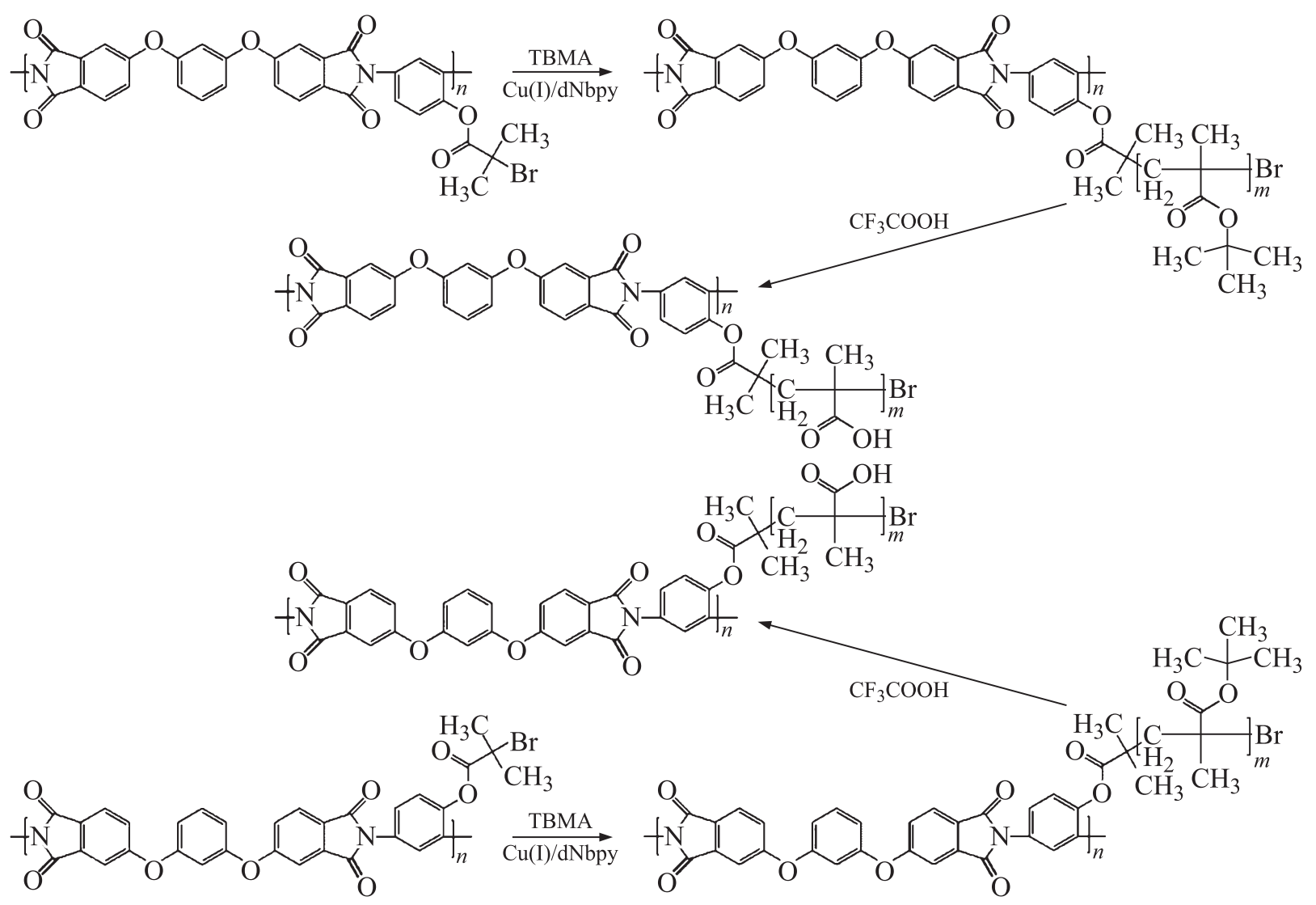

Рис. 1. Схема синтеза ПИ-прив-ПМАК методом контролируемой радикальной полимеризации с переносом атома [3,11].

Несомненный интерес для использования в ФДТ представляют АМЩ с гидрофобной полиимидной основной цепью и гидрофильными боковыми цепями полиметакриловой кислоты ПИ-прив-ПМАК [3,11]. Щетки ПИприв-ПМАК при высоких значениях степени полимеризации боковых цепей ПМАК и плотности их прививки обладают хорошей растворимостью в воде и проявляют способность инкорпорировать в гидрофобную часть лекарственные препараты за счет гидрофобных взаимодействий [11].

Нуль-валентный селен $\left(\mathrm{Se}^{0}\right)$, который представляет собой гидрофобный неорганический полимер, обладает комплексом уникальных биомедицинских свойств, одним из которых является высокая противоопухолевая активность [4,12-16], вследствие чего $\mathrm{Se}^{0}$ может быть использован в качестве агента для загрузки в АМЩ с последующим применением в диагностике и лечении методом ФДТ.

Ввиду того что для бинарных систем наблюдается синергизм свойств исходных компонентов, в настоящей работе синтезированы новые бинарные наносистемы (БН): 1 - на основе водорастворимых молекулярных щеток ПИ-прив-ПМАК и Радахлорина ${ }^{\circledR}$,

2 - на основе водорастворимых молекулярных щеток ПИ-прив-ПМАК и наночастиц $\mathrm{Se}^{0}$.
Изучены их морфологические, спектральные и молекулярно-конформационные характеристики методами атомно-силовой микроскопии (АСМ), УФ-спектроскопии в видимой области и динамического/статического светорассеяния.

\section{1. Экспериментальная часть}

Синтез амфифильных молекулярных щеток ПИ-привПМАК осуществляли способом „прививка от“ методом контролируемой радикальной полимеризации с переносом атома (ATRP) на полиимидном мультицентровом макроинициаторе через промежуточное образование молекулярной щетки с боковыми цепями поли $($ mpemбутилметакрилата) (ПТБМА) (щетки прекурсора) ПИприв-ПТБМА. Далее путем кислотного гидролиза звеньев боковых цепей трет-бутилметакрилата получали АМЩ с гидрофильными звеньями полиметакриловой кислоты в боковых цепях (схема показана на рис. 1) [3,11].

Бинарные наносистемы ПИ-прив-ПМАК/Радахлорин ${ }^{\circledR}$ и ПИ-прив-ПМАК $/ \mathrm{Se}^{0}$ синтезировали по единой схеме с соотношением $v$-компонентов ПИ-привПМАК: Радахлорин ${ }^{\circledR}$ или ПИ-прив-ПМАК: $\mathrm{Se}^{0}$, равным 10:1. 
Измерения оптической плотности $(D)$ водных растворов АМЩ и бинарных наносистем ПИ-прив-ПМАК $/ \mathrm{Se}^{0}$ проводили на спектрофотометре „Specord M-40“ (Carl Zeiss Jena, Германия) в диапазоне длин волн от 185 до $900 \mathrm{~nm}$ с толщиной фотометрического слоя $1 \mathrm{~cm}$.

Гидродинамические радиусы амфифильных молекулярных щеток $\left(R_{h}\right)$ и БН ПИ-прив-ПМАК/Радахлорин ${ }^{\circledR}$ и ПИ-прив-ПМАК $/ \mathrm{Se}^{0}\left(R_{h}^{*}\right)$, определяли методом динамического светорассеяния (ДСР) на корреляционном спектрометре PhotoCorComplex (источник света - гелий-неоновый лазер фирмы Coherent мощности $20 \mathrm{~mW}$ с длиной волны $\lambda=632.8 \mathrm{~nm}$ ) с программируемым коррелятором Photocor-FC (число каналов 288, ООО „Фотокор“, Россия).

Анализ корреляционной функции осуществляли с помощью программы обработки данных динамического светорассеяния Dynals. Величины гидродинамических радиусов $R_{h}, R_{h}^{*}$ рассчитывали из значений коэффициентов диффузии $\left(D^{*}\right)$ по уравнению Эйнштейна-Стокса $R_{h}=k T / 6 \pi \eta_{0} D^{*}\left(\eta_{0}\right.$ - вязкость растворителя, $k-$ константа Больцмана, $T$ - температура) [17].

Методом статического светорассеяния (ССР) [18] определяли среднеквадратичные радиусы инерции амфифильных молекулярных щеток $R_{g}$, средневесовые молекулярные массы АМЩ $M_{w}$ и величины второго вириального коэффицента $A_{2}$. Статическое светорассеяние для АМЩ анализировали в двойных координатах Зимма при $\lambda=632.8 \mathrm{~nm}$ [3]. Инкременты показателей преломления определяли измерением показателей преломления растворов $(n)$ и растворителя (вода) (ns) на рефрактометре марки RA-620, использующем лазер с длиной волны $\lambda=589 \mathrm{~nm}$, при нескольких концентрациях, затем проводили линейную экстраполяцию $\Delta n(c)=n-n_{s}$ по методу наименьших квадратов.

Среднеквадратичные радиусы инерции $\left(R_{g}^{*}\right)$ БН ПИ-прив-ПМАК/Радахлорин ${ }^{\circledR}$ и ПИ-прив-ПМАК $/ \mathrm{Se}^{0}$ измеряли на фотогониодиффузометре „Fica“ при длине волны падающего вертикально поляризованного света $\lambda=546.1 \mathrm{~nm}$ (длина волны, при которой величина оптической плотности $D$ практически минимальна [3]). Очистку растворов проводили через мембранный фильтр (Millex-HV) диаметром $0.45 \mu \mathrm{m}$. Обработку результатов измерений светорассеяния для определения $R_{g}^{*}$ (для наносистем ПИ-прив-ПМАК/Радахлорин ${ }^{\circledR}$ ) проводили по методу Дебая [17]: на основании данных по значениям асимметрии рассеяния $[z]=\lim \left(R_{45}^{\circ} / R_{135}^{\circ}\right)$ при $c \rightarrow 0 \quad\left(R_{45}^{\circ}\right.$ и $R_{135}^{\circ}-$ отношение Рэлея при углах рассеяния $\theta=45$ и $135^{\circ}$ ) определяли табулированное соотношение $D^{*} / \lambda$, где $D^{*}$ - диаметр частицы и соответственно величину $R_{g}^{*}$. По соотношению экспериментальных величин $R_{g}\left(R_{g}^{*}\right)$ и $R_{h}\left(R_{h}^{*}\right)$ находили значение структурно-конформационного параметра $\rho=R_{g} / R_{h}\left(\rho^{*}=R_{g}^{*} / R_{h}^{*}\right)[19]$.

Морфологические исследования свободных АМЩ и соответствующих БН проводили на атомно-силовом микроскопе Nanotop NT-206 (ОДО „Микротестмашины“,

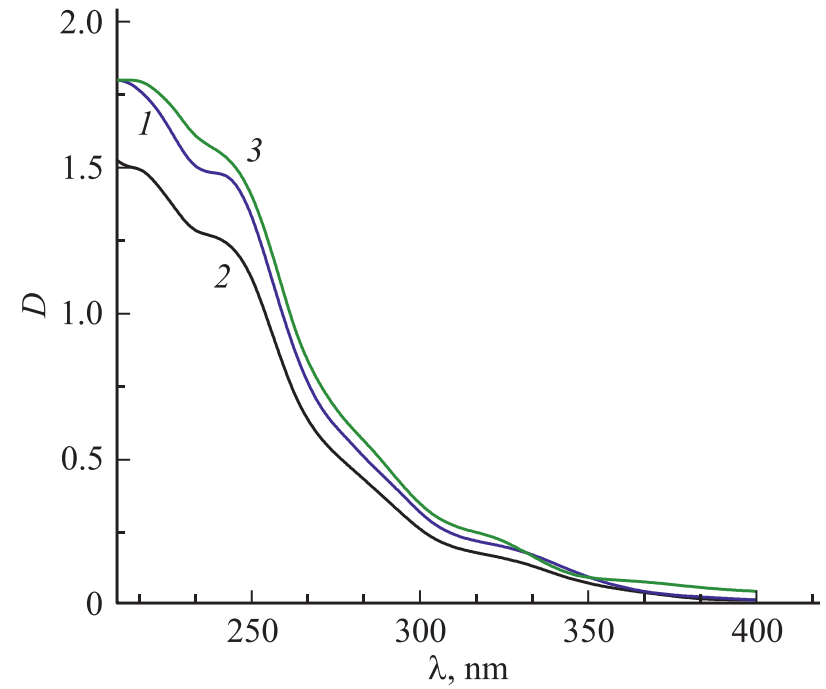

Рис. 2. Оптические спектры поглощения привитых сополимеров ПИ с боковыми цепями полиметакриловой кислоты (ПМАК) с варьируемой плотностью прививки $\mathrm{Z}$ боковых цепей (ПИ-прив-ПМАК); Z: 1 - 50, $2-80,3-100 \%$.

Беларусь). Измерения выполняли в контактном режиме в атмосферных условиях с использованием кремниевых кантилеверов NSC11/AlBS с коэффициентом жесткости $k=3.0 \mathrm{~N} / \mathrm{m}$ и радиусом кривизны кончика острия $10 \mathrm{~nm}$. Экспериментальные данные обрабатывали с помощью программы Surface Explorer. Растворы АМЩ и бинарных наносистем наносили на поверхность свежих сколов слюды.

\section{2. Обсуждение результатов}

Молекулярные массы боковых цепей ПМАК составляли $M_{n}=18-22 \mathrm{kDa}\left(M_{w} / M n=1.4-1.5\right)$, что соответствует 120-150 мономерных звеньев метакриловой кислоты (табл. 1). Видно, что основная цепь щеток имела практически предельно низкий для поликонденсационных полимеров индекс полидисперсности $\sim 2$. Боковые цепи образцов имели примерно одинаковую и превышающую 100 среднюю степень полимеризации $\mathrm{m}$, что обусловливало растворимость щеток в воде. Низкий индекс полидисперсности боковых цепей $\leq 1.5$ свидетельствовал о контролируемости процессов ATRP. В табл. 1 представлены так же данные по средневесовым молекулярным массам АМЩ $M_{w}$, определенным методом статического светорассеяния (ССР).

На основе охарактеризованных образцов ПИ-привПМАК были синтезированы БН ПИ-прив-ПМАК/Радахлорин ${ }^{\circledR}$ и ПИ-прив-ПМАК/Se ${ }^{0}$. Методами CCР, ДСР (динамического светорассеяния) и УФ-спектроскопии в видимой области показано влияние параметра плотности прививки Z на размерные и спектральные характеристики АМЩ, их форму в свободном состоянии и в комплексе с Радахлорином ${ }^{\circledR}$ или $\mathrm{HЧ} \mathrm{Se}^{0}$. В частности, 


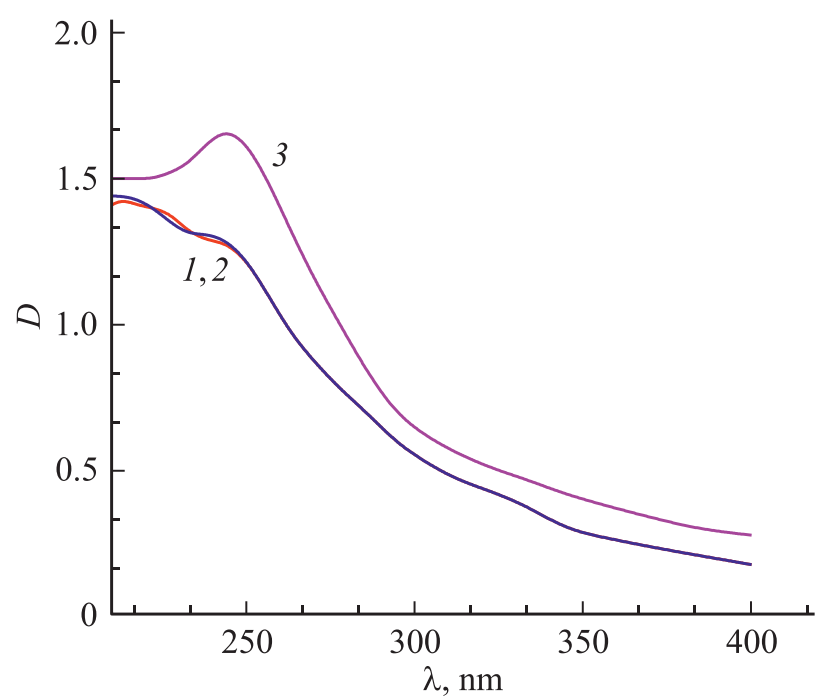

Pис. 3. Оптические спектры поглощения бинарных наносистем ПИ-прив-ПМАК/Se ${ }^{0}$; Z: $1-50,2-80,3-100 \%$.

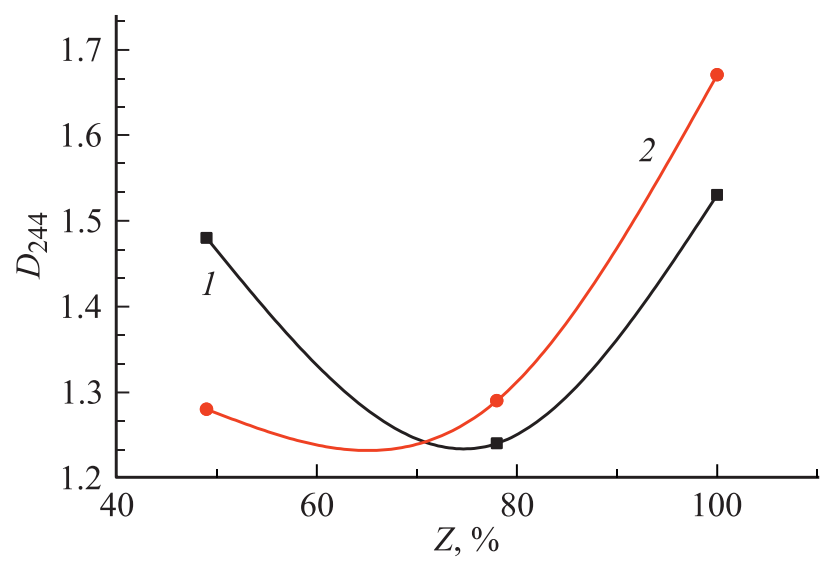

Рис. 4. Зависимость характеристической величины оптической плотности $D_{244}(D$ при $\lambda=244 \mathrm{~nm})$ от плотности прививки $\mathrm{Z}$ боковых цепей ПМАК для незагруженных амфифильных молекулярных щеток (1) и соответствующих БН ПИ-прив$\Pi$ ПАК $/ \mathrm{Se}^{0}(2)$.

показано влияние плотности прививки на характеристическую величину оптической плотности $D_{244}(D$ при $\lambda=244 \mathrm{~nm}$ ) АМЩ (рис. 2,4, кривая 1), а также БН ПИ-прив-ПМАК $/ \mathrm{Se}^{0}$ (рис. 3,4, кривая 2). Анализ рис. 3 показывает, что БН ПИ-прив-ПМАК/ $/ \mathrm{Se}^{0}$ при $Z=50$ и $80 \%$ имеют одинаковые спектры поглощения (наблюдается „плато“, как и для свободных АМЩ), а для БН ПИ-прив-ПМАК $/ \mathrm{Se}^{0}(Z=100 \%)$ при $\lambda=244 \mathrm{~nm}$ наблюдается максимум. Это может указывать на различие в механизме встраивания наночастиц $\mathrm{Se}^{0}$ в АМЩ при $Z<100$ и $Z=100 \%$.

Как видно из табл. 2, размерные характеристики (среднеквадратичный радиус инерции $R_{g}$ и гидродинамический радиус $R_{h}$ ) АМЩ с плотностями прививки $Z=80$ и $100 \%$ практически одинаковы
$\left(R_{g}=66\right.$ и $72 \mathrm{~nm}$ и $R_{h}=41$ и $42 \mathrm{~nm}$ соответственно), практически одинаковы также величины структурноконформационного параметра $\rho=R_{g} / R_{h}=1.6-1.7$. Известно, что значения $\rho^{*}=1.5$ наблюдаются для полимерных клубков в $\Theta$-растворителе [19]. Однако положительная величина второго вириального коэффициента $A_{2}=(1.0-1.6) \cdot 10^{-4} \mathrm{~cm}^{3} \mathrm{~mol} / \mathrm{g}^{2}$ для АМЩ при $\mathrm{Z}=80$ и $100 \%$ указывает на хорошее качество растворителя, поэтому величина параметра $\rho^{*}=1.6-1.7$ для данных щеток указывает на их асимметричную форму [19]. При уменьшении степени прививки до 50\% (АМЩ при $Z=50 \%$ ) качество растворителя ухудшается: $A_{2}=0$ (тэта-растворитель). Это свидетельствует о том, что гидрофобные участки основной цепи при $Z=50 \%$ перестают быть экранированными боковыми цепями ПМАК. Уменьшение величины структурно-конформационного параметра до $\rho^{*}=1.1$ указывает на то, что форма рассеивающего объекта становится более симметричной.

Ситуация кардинально меняется при переходе к бинарным наносистемам ПИ-прив-ПМАК/Радахлорин ${ }^{\circledR}$ и ПИ-прив-ПМАК $/ \mathrm{Se}^{0}$ (табл. 2). Видно, что для всех БН величина структурно-конформационного параметра $\rho^{*}=R_{g}^{*} / R_{h}^{*}$ близка к единице, что свидетельствует о сферической форме наноструктур в растворе. Среднеквадратичные радиусы инерции БН (параметр $R_{g}^{*}$ отражает геометрические размеры объекта) на основе АМЩ с относительно плотно привитыми цепями $(\mathrm{Z} \geq 80 \%)$ меньше, чем $R_{g}^{*}$ соответствующих „свободных“ АМЩ (табл. 2), т.е. для АМЩ $(Z \geq 80 \%)$ при нагружении их наночастицами $\mathrm{Se}^{0}$ изменяются и форма, и размеры наноструктур. По-видимому, введение в водные растворы препарата Радахлорина ${ }^{\circledR}$, содержащего гидрофобные группы, или гидрофобных НЧ селена, обусловливающее ухудшение термодинамического качества растворителя относительно АМЩ, приводит к „поджатию“ макромолекул щеток в составе БН.

В случае относительно редкой прививки боковых цепей $(Z=50 \%)$ форма селен-содержащих наноструктур остается сферической, а размеры по сравнению со „свободной ${ }^{6}$ АМЩ возрастают. В этом случае, повидимому, имеет место „загрузка“ $\mathrm{HЧ} \mathrm{Se}^{0}$ в мицеллы, „скрепленные“ взаимодействием „оголенных“ гидрофобных участков основной цепи АМЩ. Достижение минимальных размеров в случае БН ПИ-прив-ПМАК $/ \mathrm{Se}^{0}$ при $\mathrm{Z}=100 \%$, указывает на наиболее активный „захват“ $\mathrm{HЧ}$ $\mathrm{Se}^{0}$ амфифильными молекулярными щетками с максимальной степенью прививки и, как следствие, максимальную „гидрофобизацию“ наноструктур в растворе. В случае БН ПИ-прив-ПМАК/Радахлорин ${ }^{\circledR}$ минимальные размеры достигаются при $Z=80 \%$, что указывает на наиболее активный „захват““ молекул Радахлорина ${ }^{\circledR}$ именно этой щеткой.

На рис. 5 представлены АСМ-изображения фрагментов поверхности тонких пленок, полученных из водных растворов АМЩ с различной плотностью прививки (рис. $5, a-c)$ и БН с Радахлорином ${ }^{\circledR}$ или наночастицами $\mathrm{Se}^{0}$ на поверхности слюды. На поверхности пленки 
Таблица 1. Молекулярно-массовые характеристики амфифильных молекулярных щеток ПИ- прив-ПМАК с разной плотностью прививки $(\mathrm{Z}, \%)$ боковых цепей ПМАК

\begin{tabular}{|c|c|c|c|}
\hline$Z, \%$ & Основная цепь ПИ & Боковые цепи ПМАК & $M_{w} \cdot 10^{-3}, \mathrm{~g} / \mathrm{mol}$ \\
\hline 50 & \multirow{3}{*}{$\begin{array}{l}M_{n}=35000 \\
M_{w} / M_{n}=2.1 ; n=55\end{array}$} & $M_{n}=22000 ; m=150 ; M_{w} / M_{n}=1.4$ & 910 \\
\hline 80 & & $M_{n}=19000 ; m=125 ; M_{w} / M_{n}=1.5$ & 860 \\
\hline 100 & & $M_{n}=17700 ; m=120 ; M_{w} / M_{n}=1.5$ & 1100 \\
\hline
\end{tabular}

При ме чан и е. $n$ и $m-$ средняя степень полимеризации соответственно основной цепи и боковых цепей.

Таблица 2. Размерные и структурно-конформационные параметры свободных АМЩ с различными параметрами плотности прививки $(\mathrm{Z})$ боковых цепей ПМАК, и соответствующих БН на их основе с Радахлорином ${ }^{\circledR}$ или наночастицами $\mathrm{Se}^{0}$

\begin{tabular}{|c|c|c|c|c|}
\hline Образец & $R_{g}^{*}, \mathrm{~nm}$ & $R_{h}^{*}, \mathrm{~nm}$ & $\rho^{*}=R_{g}^{*} / R_{h}^{*}$ & $R_{\mathrm{ACM}}, \mathrm{nm}$ \\
\hline ПИ-прив-ПМАК I ( $Z=50 \%)$ & 47 & 41 & 1.1 & $25-50$ \\
\hline ПИ-прив-ПМАК II (Z=80\%) & 66 & 41 & 1.6 & $35-75$ \\
\hline ПИ-прив-ПМАК III (Z=100\%) & 72 & 42 & 1.7 & $75-100$ \\
\hline ПИ-прив-ПМАК/Радахлорин ${ }^{\circledR}(\mathrm{Z}=50 \%)$ & 43 & 38 & 1.1 & $75-150$ \\
\hline ПИ-прив-ПМАК/Радахлорин ${ }^{\circledR}(Z=80 \%)$ & 35 & 33 & 1.1 & $35-50$ \\
\hline ПИ-прив-ПМАК/Радахлорин ${ }^{\circledR}(Z=100 \%)$ & 47 & 44 & 1.1 & $100-150$ \\
\hline ПИ-прив-ПМАК/Sе ${ }^{0}(\mathrm{Z}=50 \%)$ & 60 & 70 & 0.9 & $80-120$ \\
\hline ПИ-прив-ПМАК $/ \mathrm{Se}^{0}(\mathrm{Z}=80 \%)$ & 58 & 56 & 1.0 & $50-80$ \\
\hline ПИ-прив-ПМАК $/ \mathrm{Se}^{0}(\mathrm{Z}=100 \%)$ & 47 & 47 & 1.0 & $30-50$ \\
\hline
\end{tabular}

Таблица 3. Значения средней арифметической $\left(R_{a}\right)$ и средней квадратичной $\left(R_{q}\right)$ шероховатости поверхности пленок, полученных из водных растворов свободных АМЩ, в зависимости от плотности прививки $(Z)$ боковых цепей ПМАК, и соответствующих БН на их основе с Радахлорином ${ }^{\circledR}$ или наночастицами $\mathrm{Se}^{0}$

\begin{tabular}{l|l|l|l}
\hline Образец & $\mathrm{Z}=50 \%$ & $\mathrm{Z}=80 \%$ & $\mathrm{Z}=100 \%$ \\
\hline \multirow{2}{*}{ ПИ-прив-ПМАК } & $R_{a}=0.8 \mathrm{~nm}$ & $R_{a}=0.6 \mathrm{~nm}$ & $R_{a}=0.4 \mathrm{~nm}$ \\
& $R_{q}=1.2 \mathrm{~nm}$ & $R_{q}=1.0 \mathrm{~nm}$ & $R_{q}=.5 \mathrm{~nm}$ \\
\hline \multirow{2}{*}{ ПИ-прив-ПМАК/Радахлорин ${ }^{\circledR}$} & $R_{a}=1.8 \mathrm{~nm}$ & $R_{a}=0.9 \mathrm{~nm}$ & $R_{a}=2.0 \mathrm{~nm}$ \\
& $R_{q}=2.5 \mathrm{~nm}$ & $R_{q}=1.1 \mathrm{~nm}$ & $R_{q}=3.2 \mathrm{~nm}$ \\
\hline \multirow{2}{*}{ ПИ-прив-ПМАК/Sе } & $R_{a}=5.9 \mathrm{~nm}$ & $R_{a}=1.4 \mathrm{~nm}$ & $R_{a}=1.0 \mathrm{~nm}$ \\
& $R_{q}=8.4 \mathrm{~nm}$ & $R_{q}=2.2 \mathrm{~nm}$ & $1.4 \mathrm{~nm}$
\end{tabular}

АМЩ с плотностью прививки $\mathrm{Z}=50 \%$ (рис. 5, 1 ) наблюдается зернистая морфология - обнаружены мелкие зерна, связанные между собой перетяжками толщиной $\sim 50 \mathrm{~nm}$ и длиной до $400 \mathrm{~nm}$. Радиус зерен составляет 25-50 nm (табл. 2), а высота зерен над поверхностью не превышает $3 \mathrm{~nm}$. Можно предположить, что перетяжки представляют собой жгутики из нескольких распрямленных и переплетенных макромолекул этой молекулярной щетки. Оценка средней арифметической $\left(R_{a}\right)$ и средней квадратичной $\left(R_{q}\right)$ шероховатости поверхности пленки с $\mathrm{Z}=50 \%$, дает значения $R_{a}=0.8 \mathrm{~nm}$ и $R_{q}=1.2 \mathrm{~nm}$ (табл. 3). Образец с плотностью прививки $\mathrm{Z}=80 \%$ (рис. $5, b$ ) имеет такой же характер морфологии, как у пленки с $Z=50 \%$, однако в этом случае наблюдается значительно большее количество более крупных зерен с радиусом от 35 до $75 \mathrm{~nm}$ (табл. 2), при этом шероховатость практически не изменяется $R_{a}=0.6$ и $R_{q}=1.0 \mathrm{~nm}$ соответственно (табл. 3 ).

Совершенно другая картина наблюдается для пленки АМЩ с плотностью прививки $Z=100 \%$. На рис. 5, с видно, что поверхность пленки становится практически гомогенной и гладкой, зерна значительно укрупняются, их размеры достигают 75-100 nm (табл. 2), при этом высота над поверхностью подложки менее $1.5 \mathrm{~nm}$, а $R_{a}=0.4 \mathrm{~nm}$ и $R_{q}=0.5 \mathrm{~nm}$ (табл. 3). При увеличении параметра плотности прививки $\mathrm{Z}$ (рис. 6, кривая 1) четко прослеживается тенденция возрастания средних размеров формирующихся зерен незагруженных АМЩ.

Бинарные наносистемы ПИ-прив-ПМАК/Радахлорин ${ }^{\circledR}$ (рис. 5, $d-f$ ) значительно отличаются по морфологическим характеристикам от свободных АМЩ. Сравнение АСМ-изображений фрагментов поверхности тон- 

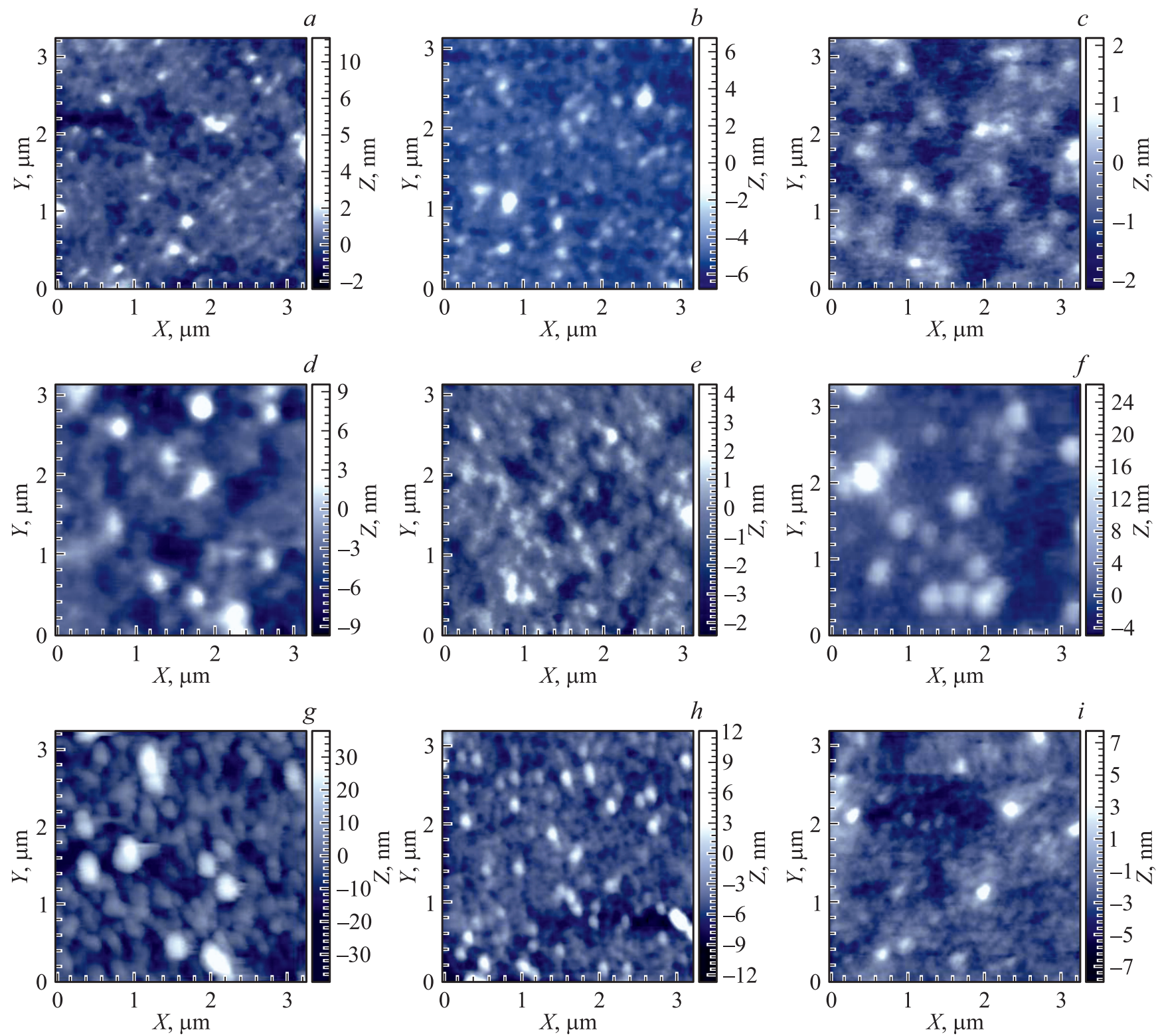

Рис. 5. АСМ-изображения поверхности тонких пленок, полученных из водных растворов АМЩ на слюде, при варьировании параметра плотности прививки Z $(a-c)$, БН ПИ-прив-ПМАК/Радахлорин $(d-f)$ и БН ПИ-прив-ПМАК/Se $(g-i): a, d, g-\mathrm{Z}=50 \%$; $b, e, h-\mathrm{Z}=80 \% ; c, f, i-\mathrm{Z}=100 \%$.

ких пленок, полученных из водных растворов БН с Радахлорином ${ }^{\circledR}$ на основе АМЩ с разной плотностью прививки Z, показывает существенную разницу в морфологии. Так, для АМЩ с плотностью прививки $Z=50 \%$ (рис. $5, d)$ БН, содержащие Радахлорин ${ }^{\circledR}$, представляет собой достаточно крупные симметричные образования, диаметр которых изменяется в пределах 200-300 $\mathrm{nm}$. При этом $R_{a}=1.8 \mathrm{~nm}$ и $R_{q}=2.5 \mathrm{~nm}$ (табл. 3), т.е. в два раза выше, чем у свободной АМЩ с $\mathrm{Z}=50 \%$.

Морфология поверхности пленки ПИ-прив-ПМАК/Радахлорин $^{\circledR}$ кардинально изменяется при увеличении плотности прививки до $80 \%$ (рис. $5, e$ ). Поверхность этого образца состоит из мелких зерен неправильной формы, размеры которых составляют 35-50 nm (табл. 2).
Следует отметить, что значения параметров шероховатости уменьшаются примерно в два раза до $R_{a}=0.9 \mathrm{~nm}$ и $R_{q}=1.1 \mathrm{~nm}$ (табл. 3). Напротив, при увеличении плотности прививки $\mathrm{Z}$ до $100 \%$ (рис. $5, f$ ) на поверхности пленки наблюдается большое количество крупных зерен сферической формы диаметром 150-300 nm, высота которых над поверхностью подложки достигает $14 \mathrm{~nm}$. Таким образом, установлено, что зависимость средних размеров БН ПИ-прив-ПМАК/Радахлорин ${ }^{\circledR}$ от параметра плотности прививки $Z$ имеет экстремальный характер с минимумом при $Z=80 \%$ (рис. 6 , кривая 2 ).

Введение наночастиц $\mathrm{Se}^{0}$ в АМЩ значительно изменяет характер морфологии поверхности пленок синтезированных образцов. Сравнение АСМ-изображений 


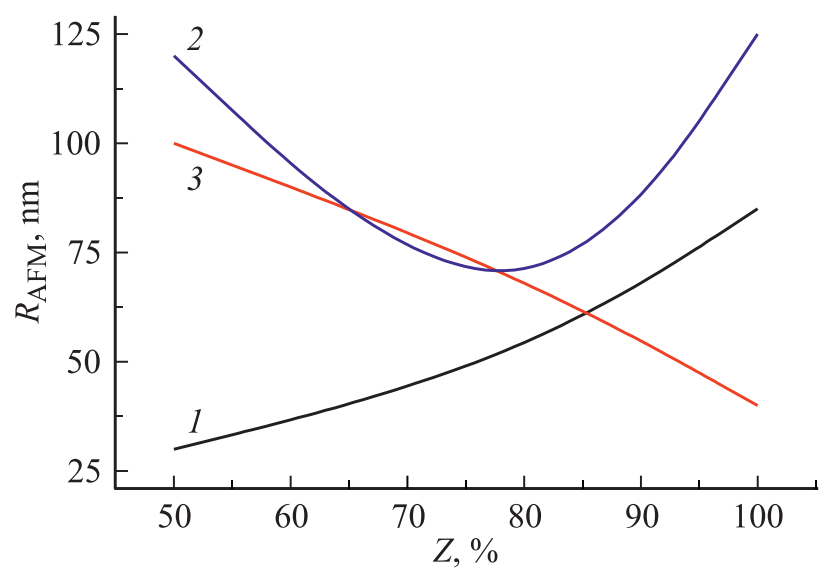

Рис. 6. Зависимость величин радиуса наноструктур, определенных методом АCM, от параметров плотности прививки Z боковых цепей ПМАК: 1 - незагруженные щетки ПИ-привПМАК, 2 - БН ПИ-прив-ПМАК/Радахлорин ${ }^{\circledR}, 3-$ БН ПИприв-ПМАК $/ \mathrm{Se}^{0}$.

фрагментов поверхности тонких пленок, полученных из водных растворов БН ПИ-прив-ПМАК $/ \mathrm{Se}^{0}$ на основе АМЩ с разной плотностью прививки $Z$ (рис. $5, g-i$ ), показывает существенную разницу в размерах сформировавшихся на поверхности подложки наноструктур (табл. 2). При этом четко прослеживается тенденция значительного уменьшения размеров наноструктур $R_{\mathrm{ACM}}$ и снижения шероховатости в несколько раз при увеличении параметра плотности прививки Z (рис. 6, кривая 3).

\section{Выводы}

1. Методом АСМ изучена морфология поверхностей пленок свободных амфифильных молекулярных щеток ПИ-прив-ПМАК с разной плотностью прививки $\mathrm{Z}$ боковых цепей ПМАК и БН с Радахлорином ${ }^{\circledR}$ или НЧ $\mathrm{Se}^{0}$. Установлено, что в водных растворах БН ПИ-привПМАК $/ \mathrm{Se}^{0}$ образуются сферические наноструктуры, для которых характерна тенденция уменьшения размеров и параметров шероховатости с увеличением плотности прививки $Z$ боковых цепей ПМАК. Напротив, зависимость размеров наноструктур и параметров шероховатости БН ПИ-прив-ПМАК/Радахлорин ${ }^{\circledR}$ от параметра прививки боковых цепей имеет экстремальный характер с минимумом при $Z=80 \%$.

2. Методами статического и динамического светорассеяния установлено, что в водных растворах бинарных наносистем ПИ-прив-ПМАК/Se ${ }^{0}$, независимо от $\mathrm{Z}$, формируются сферические наноструктуры с тенденцией уменьшения размеров при увеличении Z. При этом обнаружено, что геометрические размеры наноструктур ПИприв-ПМАК $/ \mathrm{Se}^{0}$ при $\mathrm{Z} \geq 80 \%$ меньше размеров незагруженных амфифильных молекулярных щеток ПИ-прив-
ПМАК, что обусловлено ухудшением термодинамики растворов вследствие их „гидрофобизации“.

3. Напротив, при $Z=50 \%$ за счет эффекта мицеллообразования макромолекул АМЩ, размеры БН возрастают для ПИ-прив-ПМАК/ $/ \mathrm{Se}^{0}$ или не изменяются в случае ПИ-прив-ПМАК/Радахлорин ${ }^{\circledR}$. То есть взаимодействие молекул Радахлорина ${ }^{\circledR}$ или НЧ $\mathrm{Se}^{0}$ с АМЩ („встраивание“ в щетку) в значительной степени определяется как параметром Z, так и природой вводимого агента.

Таким образом, показано, что путем контролируемого варьирования плотности прививки $\mathrm{Z}$ боковых цепей ПМАК можно целенаправленно управлять размерами и формой загруженных Радахлорином ${ }^{\circledR}$ или $\mathrm{HЧ} \mathrm{Se}^{0}$ бинарных наносистем на основе амфифильных молекулярных щеток.

Полученные результаты составляют физикохимическую основу для использования амфифильных молекулярных щеток в нанобиотехнологических разработках для создания на их основе наноконтейнеров, загруженных лекарственными препаратами.

\section{Благодарности}

Авторы выражают благодарность И.В. Иванову (ИВС РАН) за помощь в синтезе образцов АМЩ и М.Л. Гельфонду (НМИЦ онкологии им. Н.Н. Петрова МЗ РФ) за предоставленный препарат Радахлорин ${ }^{\circledR}$.

\section{Финансирование работы}

Работа выполнена при поддержке РФФИ, грант № $17-$ 53-61026 Египет_а.

\section{Конфликт интересов}

Авторы заявляют, что у них нет конфликта интересов.

\section{Список литературы}

[1] Xie G., Martinez M.R., Olszewski M., Sheiko S.S., Matyjaszewski K. // Biomacromolecules. 2019. Vol. 20. P. 27 54. https://doi.org/10.1021/acs.biomac.8b01171

[2] Pelras T., Mahon C.S., M'ullner M. // Angew. Chem. Int. Ed. 2018. Vol. 57. P. 6982-6994. https://doi.org/10.1002/anie.201711878

[3] Валуева С.В., Вылегжсанина М.Э., Мелешко Т.К., Иванов И.В., Гасилова Е.Р., Гельфонд М.Л., Якиманский А.В., Суханова Т.Е. // ЖПХ. 2020. Т. 93. Вып. 1. С. 164-174.

[4] Валуева С.В., Вылегжанина М.Э., Суханова Т.Е. // Сборник статей XXV Междунар. научно-практической конф. Фундаментальные и прикладные научные исследования: актуальные вопросы, достижения и инновации. Пенза МЦНС „Наука и просвещение“. Ч. 1. С. 13-18.

[5] Sukhanova T.E., Gelfond M.L., Bershtein V.A., Valueva S.V., Vylegzhanina M.E., Volkov A.Ya., Kutin A.A., Matveeva G.N. Ch. 9. In „Photodynamic Therapy: Fundamentals, Applications and Health Outcomes". Nova Science Publishers, Inc., NY. USA. 2015. Ed. A.G. Hugo. P. 207-224. 
[6] Суханова Т.Е., Валуева С.В., Иванов И.В., Мелешко Т.К., Вылегжсанина М.Э., Гельфонд М.Л., Якиманский А.В. // Нанотехнологии: наука и производство. 2017. № 4. С. 311.

[7] Суханова Т.Е., Вылегжанина М.Э., Валуева С.В., Мелешко Т.К., Иванов И.В., Гасилова Е.Р., Филиппов А.П., Якиманский А.В., Гельфонд М.Л. // Тр. XXII Междунар. симп. „Нанофизика и наноэлектроника“. Нижний Новгород, 2018. Т. 1. С. 363-364.

[8] Валуева С.В., Боровикова Л.Н., Суханова Т.Е. Исследование комплексообразования фотодитазина с наночастицами селена и селенида цинка. // Тез. докл. XII Всерос. конф. с международным участием „Проблемы сольватации и комплексообразования в растворах. От эффектов в растворах к новым материалам“. Иваново, 2015. С. 182-183.

[9] Пат. РФ 2523380 (опубл. 2006). Фотосенсибилизатор и способ его получения.

[10] Wainwright M. // J. Antimicrob. Chemother. 1998. Vol. 42. P. 13-28. https://doi.org/10.1093/jac/42.1.13

[11] Yakimansky A.V., Meleshko T.K., Ilgach D.M., Bauman M.A., Anan'eva T.D., Klapshina L.G., Lermontova S.A., Balalaeva I.V., Douglas W.E. // J. Polym. Sci. Part A: Polym. Chem. 2013. Vol. 51. N 20. P. 4267-4281. https://doi.org/10.1002/pola.26846

[12] Валуева С.В., Боровикова Л.Н., Коренева В.В. и др. // ЖФХ. 2007. Т. 81. № 1. С. 1329-1333. [Valueva S.V., Borovikova L.N., Koreneva V.V. et. al. // Rus. J. Phys. Chem. A. 2007. Vol. 81. N 7. P. 1170-1173.]

[13] Валуева С.В., Суханова Т.Е., Матвеева Н.А. и др. Морфология и билогические свойства наночастиц селена, стабилизированных бычьим сывороточным альбумином и поливинилпирролидоном В сб.: Вторая междунар. научнопрактическая конф. „Высокие технологии, фундаментальные и прикладные исследования в физиологии и медицине“" (PhysioMedi). СПб., 2011. С. 130-137.

[14] Валуева С.В., Азизбекян С.Г., Кучинский М.П. и др. // Нанотехника. 2012. Т. 32. № 4. С. 53-58.

[15] Sukhanova T.E., Valueva S.V., Vylegzhanina M.E. et al. Ch. 6. In „Selenium: Dietary Sources, Properties and Role in Human Health“. Nova Science Publishers, Inc. NY. USA., 2015. Ed. Wanda Morrison. P. 159-173.

[16] Валуева С.В., Боровикова Л.Н. В сб.: Междунар. научнопрактическая конф. „Инновационное развитие науки и образования“, Пенза МЦНС „Наука и просвещение“. Ч. 1. 2018. C. 23-28.

[17] Brown $W$. Dynamic Light Scattering: The Method and Same Application (Clarendon, Oxford, 1993). 735 p.

[18] Эскин B.E. Рассеяние света растворами полимеров и свойства макромолекул. Л.: Наука, 1986. 288 с.

[19] Burchard B.W. // Laser Light Scattering in Biochemistry / Eds. by Harding S.E., Satelle D.B., Bloomfield V.A. Cambridge: Royal Soc. Chem. 1992. Information Services. P. 3-21. 